\title{
Molecular analysis of an extracellular protease gene from Vibrio parahaemolyticus
}

\author{
Chia-Yin Lee, Shiun-Cheng Su and Ren-Bao Liaw
}

Graduate Institute of Agricultural Chemistry, National Taiwan University, Taipei, Taiwan 106, Republic of China
Author for correspondence: Chia-Yin Lee. Tel: +88623630231 ext. 2816. Fax: +88623660581. e-mail:m477@ccms.ntu.edu.tw

Keywords: cloning, sequence, Vibrio parabaemolyticus, protease gene

\section{INTRODUCTION}

Vibrio parabaemolyticus is an important diarthoeal agent associated with seafood consumption in Taiwan, Japan and many coastal areas (Janda et al., 1988). A number of possible virulence factors, including haemolysin (Nishibuchi et al., 1992), lethal toxins (Sarkar et al., 1987a, b) and vascular permeability factors (Honda et al., 1976), have been demonstrated to be associated with the pathogenicity of this species. Among the haemolysins, the thermostable direct haemolysin (TDH) has been established as an important virulence factor contributing to the enteropathogenesis of $V$. parabaemolyticus (Nishibuchi et al., 1992). However, other studies have reported that haemolysin or TDH may not be the sole major lethal factor for mice, and that other toxic factors lethal for mice may be present in environmental nonhaemolytic $V$. parabaemolyticus strains (Dai et al., 1992; Yoh et al., 1992).

In addition, it has been suggested that extracellular bacterial proteases may play an important role in virulence and may serve as useful industrial enzymes (Häse \&

Abbreviation: $T D H$, thermostable direct haemolysin.

The EMBLGenBank accession number for the prtVp nucleotide sequence data presented in this paper is $\mathrm{Z} 46782$.
Finkelstein, 1993). Legionella pneumophila metalloprotease exhibits haemolytic and cytotoxic activities (Dowling et al., 1992). Vibrio cholerae haemagglutinin/protease (Finkelstein et al., 1992) nicks and activates the A subunit of the cholera enterotoxin (Booth et al., 1984), and the corresponding gene has been cloned and sequenced (Häse \& Finkelstein, 1991). The isolation and characterization of alkaline serine exoproteases and a collagenase of $V$ ibrio alginolyticus has been reported (Deane et al., 1986, 1989; Takeuchi et al., 1992). Vibrio proteolyticus neutral protease has industrial applications in the synthesis of dipeptides (David et al., 1992). A purified extracellular metalloprotease from Vibrio mimicus has been demonstrated to enhance vascular permeability in skin and fluid accumulation in rabbit ileal loops (Chowdhury et al., 1991a, b). An elastase from Vibrio anguillarum has been isolated and characterized, and the corresponding gene has also been cloned and sequenced (Milton et al., 1992; Norqvist $e t$ al., 1990).

Unlike other Vibrio proteases, little is known about the proteases in $V$. parabaemolyticus (Iuchi \& Tanaka, 1982). This paper describes the cloning and sequencing of a gene encoding a metalloprotease of $V$.parabaemolyticus and the biochemical characterization of the partially purified protease. 


\section{METHODS}

Bacterial strains and plasmids. These are listed in Table 1. A $5.8 \mathrm{kbp}$ HindIII DNA fragment from plasmid pVH21 was subcloned in the vector plasmid pUC119. The resulting recombinant plasmid was designated pLS101.

Media and growth conditions. Escherichia coli strain XL1-Blue was grown at $35^{\circ} \mathrm{C}$ in LB broth (Miller, 1972). LB medium supplemented with $100 \mu \mathrm{g}$ ampicillin $\mathrm{ml}^{-1}$ (Sigma) was used for this strain when bearing a vector or recombinant plasmid. To isolate chromosomal DNA, $V$. parabaemolyticus was grown in tryptic soy broth (TSB; BBL Microbiology Systems) supplemented with $3 \%$ (w/v) $\mathrm{NaCl}$ at $35^{\circ} \mathrm{C}$. Transformed E. coli cells were selected on LB plates supplemented with ampicillin $(100 \mu \mathrm{g}$ $\left.\mathrm{ml}^{-1}\right)$ and tetracycline $\left(10 \mu \mathrm{g} \mathrm{ml}^{-1}\right)$ or on LB plates containing

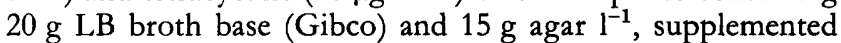
with $100 \mu \mathrm{g}$ ampicillin $\mathrm{ml}^{-1}, 0.2 \mathrm{mM}$ IPTG (Sigma), and 0.004 \% X-Gal (Sigma).

DNA preparation and molecular biological techniques. Isolation of plasmids, restriction endonuclease digestion, agarose gel electrophoresis of DNA, and purification of DNA fragments were done as described by Ausubel et al. (1987).

Southern blot hybridization. The isolated DNA fragment, a $5.8 \mathrm{kbp}$ HindIII fragment carrying the $p r t V p$ gene, was ${ }^{32} \mathrm{P}$. labelled by using a random primed DNA labelling kit (Boehringer Mannheim) according to the directions of the manufacturer. Alkaline Southern blot hybridization was performed as described previously by Lee \& Pan (1993).

Construction of a genomic library. The following steps were performed as described in the method of Ausubel et al. (1987). Chromosomal DNA of $V$. parabaemolyticus was extracted by SDS/proteinase $\mathrm{K}$ lysis followed by hexadecyltrimethylammonium bromide treatment, two phenol/chloroform/ isoamyl alcohol extractions and ethanol precipitation. The purified DNA was then suspended in small volumes of TE buffer $(10 \mathrm{mM}$ Tris $/ \mathrm{HCl}$ containing $1 \mathrm{mM}$ EDTA, $\mathrm{pH} 8)$, partially digested with HindIII (BRL) and fractionated on a $1 \%$ $(\mathrm{w} / \mathrm{v})$ agarose gel. DNA fragments of $5-12 \mathrm{kbp}$ were isolated by using a Jetsorb DNA extraction kit (Genomed). The DNA fragments were ligated with the T4 DNA ligase (BRL) into HindIII (BRL)-digested pBR322 previously dephosphorylated. Ligated pBR322 DNA mixtures were transformed into com- petent E. coli strain XL1-Blue according to the procedure of Ausubel et al. (1987).

Assay for protease. Protease activity was detected by the hydrolysis of gelatin in solidified agarose. Cultures were placed on LB agar containing $2 \%(\mathrm{w} / \mathrm{v})$ gelatin and incubated at $35^{\circ} \mathrm{C}$ for 1-2 d. A clear zone around the colony was detected after the agar plate was flooded with $15 \%$ (w/v) $\mathrm{HgCl}_{2}\left(3 \mathrm{~g} \mathrm{HgCl}_{2}\right.$ in $4 \mathrm{ml} \mathrm{HCl}$ and water added for a total volume of $20 \mathrm{ml}$ ) (Norqvist et al., 1990). For detection of protease activity in SDSpolyacrylamide gels, $0.2 \%$ gelatin was copolymerized in the $10 \%(\mathrm{w} / \mathrm{v})$ polyacrylamide matrix. The gel was soaked in $2.5 \%$ (w/v) Triton X-100 for $1 \mathrm{~h}$ at $25^{\circ} \mathrm{C}$, incubated at $37^{\circ} \mathrm{C}$ for $4 \mathrm{~h}$

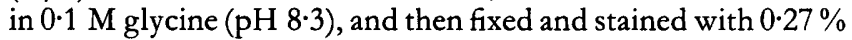
Coomassie brilliant blue (Bio-Rad, R-250) in methanol/acetic acid/water (50:10:40, by vol.). Finally, the gel was destained with $7 \%(\mathrm{v} / \mathrm{v})$ acetic acid $/ 7 \%(\mathrm{v} / \mathrm{v})$ methanol, and the clear zones in the SDS-gelatin-polyacrylamide gel were detected (Heussen \& Dowdle, 1980).

Preparation of the protease. The $V$. parabaemolyticus strains were grown in $100 \mathrm{ml}$ TSB containing $3 \%$ (w/v) $\mathrm{NaCl}$ at $35^{\circ} \mathrm{C}$ for $18 \mathrm{~h}$. The bacterial cells were pelleted by centrifugation (Hitachi) at $6510 \mathrm{~g}$ for $10 \mathrm{~min}$ at $4{ }^{\circ} \mathrm{C}$. The supernatant fractions were collected, and the proteins were then precipitated on ice by the addition of solid ammonium sulphate to $50 \%$ saturation. The precipitate was pelleted by centrifugation at $4{ }^{\circ} \mathrm{C}$ for $10 \mathrm{~min}$ at $6510 \mathrm{~g}$. The pellet was resuspended in $1 \mathrm{ml} 0.01 \mathrm{M}$ potassium phosphate buffer, $\mathrm{pH} 7 \cdot 0$, and dialysed at $4{ }^{\circ} \mathrm{C}$ with changing of the buffer at least three times. After overnight dialysis, the final volume was about $1 \mathrm{ml}$. E. coli(pLS101) (Table 1) was grown in LB medium. Other stages in the preparation of protease from $E$. coli were the same as in the steps described earlier.

Protease inhibitors. EDTA (Stratagene) was used at a concentration of $10 \mathrm{mM}$. Aprotinin (Sigma) was used in 10 and $30 \mu \mathrm{g} \mathrm{ml}^{-1}$ concentrations. 1,10-Phenanthroline (Sigma), PMSF (Sigma) and pepstatin A were first dissolved in methanol and used in 1 and $10 \mathrm{mM}$ concentrations. Protease activity was measured by gelatin medium assay. Crude extracellular protease $(40 \mu \mathrm{l})$ with inhibitor was added into a hole of $4 \mathrm{~mm}$ diameter in gelatin medium and incubated at $37^{\circ} \mathrm{C}$ for $24 \mathrm{~h}$. The presence or absence of a clear zone on the gelatin medium was observed.

Haemolytic activity. Crude extracellular protease $(40 \mu \mathrm{l})$ was added into a hole of $4 \mathrm{~mm}$ diameter in NAB blood medium

Table 1. Bacterial strains and plasmids used in this study

\begin{tabular}{|c|c|c|}
\hline Strain or plasmid & Relevant genotype or phenotype & Source or reference \\
\hline Escherichia coli XL1-Blue & $\begin{array}{l}\operatorname{rec} A 1 \text { end } A 1 \text { gyr } A 46 \text { thi bsdR } 17 \text { supE } 44 \text { rel } A 1 \text { lac } \mathrm{F}^{\prime}\left[\text { pro } A B \text { lac }{ }^{\mathrm{q}}\right. \\
\left.\text { lac } Z \Delta \mathrm{M} 15 \operatorname{Tn} 10\left(\text { tet }^{\mathrm{r}}\right)\right]\end{array}$ & Bullock et al. (1987) \\
\hline Vibrio parabaemolyticus 93 & $t d h$ trh, Kanagawa phenomenon weak positive & Clinical isolate from Taiwan \\
\hline pBR322 & $A p^{r} T^{r}$ & $\begin{array}{l}\text { Bolivar et al. (1977); } \\
\text { Sutcliffe (1979) }\end{array}$ \\
\hline pUC119 & $\mathrm{Ap}^{\mathrm{r}}$ lac $Z$ & Vieira \& Messing $(1982,1987)$ \\
\hline pVH21 & $\begin{array}{l}\mathrm{Ap}^{\mathrm{r}} \mathrm{Tc}^{\mathrm{r}} \mathrm{prt}^{+}, 5 \cdot 8 \mathrm{kbp} \text { HindIII fragment carrying prtVp cloned } \\
\text { into HindIII site of } \mathrm{pBR} 322\end{array}$ & This study \\
\hline pLS101 & $\begin{array}{l}\mathrm{Ap}^{\mathrm{r}} p r t^{+}, 5.8 \mathrm{kbp} \text { HindIII fragment of } \mathrm{pVH} 21 \text { carrying } p r t V p \\
\text { subcloned into HindIII site of pUC119 }\end{array}$ & This study \\
\hline pLSD1-6 & $\begin{array}{l}\mathrm{Ap}^{\mathrm{r}} p r t^{+} \text {, exonuclease deletion derivatives of } \mathrm{pLS} 101 \text { retaining } \\
\text { the } p r t V p \text { gene }\end{array}$ & This study \\
\hline pLSD7-24 & $\begin{array}{l}A \mathrm{p}^{\mathrm{r}} \text { prt, exonuclease deletion derivatives of pLS101 deleted in } \\
\text { the } \operatorname{prtVp} \text { gene }\end{array}$ & This study \\
\hline
\end{tabular}


(nutrient agar containing $2.5 \%, \mathrm{v} / \mathrm{v}$, blood and $100 \mu \mathrm{g}$ ampicillin $\mathrm{ml}^{-1}$ ) supplemented with or without EDTA and incubated at $37^{\circ} \mathrm{C}$ for $48 \mathrm{~h}$. Haemolytic activity was measured from the diameter of the clear zone; greater than 1 and $3 \mathrm{~mm}$ were designated weak and strong reactions, respectively.

Exonuclease deletion to localize DNA fragments encoding protease activity. Unidirectional deletions with exonuclease III/S1 were performed by using the Erase-a-Base System (Promega) (Henikoff, 1984). Plasmid pLS101 was digested with BamHI and $K p n I$ to leave $5^{\prime}$ and $3^{\prime}$ overhangs, susceptible to ExoIII. Deletions were made in the $5^{\prime}$ end starting from pLS101 carrying the $5.8 \mathrm{kbp}$ HindIII insert. The series of deletion derivatives was subcloned in pUC119 to produce plasmids pLSD1-pLSD24 (Table 1) and transformed into E. coli strain XL1-Blue as described previously by Ausubel et al. (1987).

Nucleotide sequence determination. Plasmid pLSD6 containing the DNA insert to be sequenced was maintained in $E$. coli strain XL1-Blue. The complete nucleotide sequences of both strands of DNA were determined by the dideoxy chaintermination method of Sanger et al. (1977), using the Sequenase version 2.0 sequencing kit (United States Biochemical) and $\left[\alpha-{ }^{35} \mathrm{~S}\right] \mathrm{dATP}$ (NEN) as the label. Universal or synthetic oligonucleotide primers were synthesized with a DNA synthesizer (Oligo 1000, Beckman) by the Pan Asia Hospital Supply Company in Taiwan. Double-stranded template DNA was prepared by the method of Kho \& Zarbl (1992). Sequencing gels $(6 \%, \mathrm{w} / \mathrm{v}$, polyacrylamide) were prepared according to the method of Chang \& Wu (1992). After the fractionation, the gels were dried and exposed to X-ray film (DuPont Cornex).

DNA sequence analysis. The nucleotide sequence data and deduced amino acid sequence were analysed for similarity to the published sequences in the EMBL and PIR databases, using the FASTDB and PEP/ALIGN programs from IntelliGenetics (IntelliCorp), and based on the similarity search method of Wilbur \& Lipman (1983). The nucleotide sequence and amino acid sequence of PrtVp were also analysed by PC/GENE version 6.60.

\section{RESULTS}

\section{Cloning of the prtVp gene}

To clone the gene encoding an extracellular protease of $V$. parabaemolyticus strain 93, a genomic library was constructed in vector pBR322 in E. coli strain XL1-Blue. One protease-positive clone, carrying $\mathrm{pVH} 21$, was detected by screening 3000 transformants. However, the control E. coli strain XL1-Blue(pBR322) had no detectable proteolytic activity on gelatin-LB agar. Southern blot analysis verified that the $5.8 \mathrm{kbp}$ HindIII fragment in pVH21 was present in the $V$. parabaemolyticus genome (Fig. 1). Restriction analysis of the isolated plasmid revealed that $\mathrm{pVH} 21$ had one EcoRI cutting site within a $5.8 \mathrm{kbp}$ DNA insert. For determination of the nucleotide sequence, the $5.8 \mathrm{kbp}$ DNA insert in pVH21 was subcloned into vector plasmid pUC119 yielding plasmid pLS101.

\section{Identification of the plasmid-encoded proteins}

The protease was obtained from culture supernatant fractions of $V$. parabaemolyticus strains and $E$. coli(pLS101), and concentrated by ammonium sulphate precipitation. The samples were analysed for protease (a)

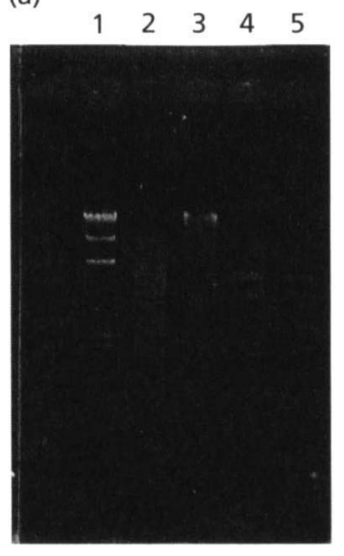

(b)

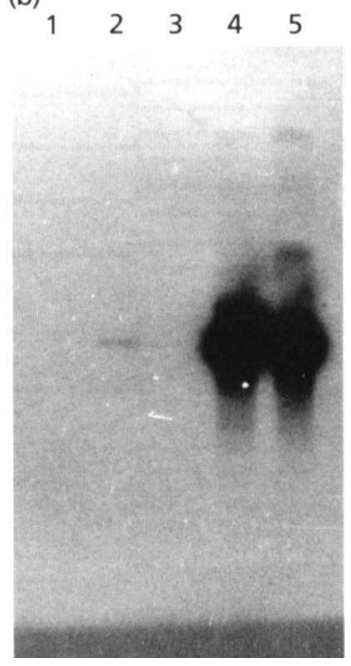

Fig. 1. Southern blot analysis confirming $V$. parahaemolyticus strain 93 as the source of insert DNA in pVH21. (a) Agarose gel electrophoresis; (b) Southern blot hybridization with the ${ }^{32} \mathrm{P}$ labelled pVH21-derived HindIII insert fragment. Lanes: 1, HindIIl-cleaved $\lambda$ DNA molecular size markers; $2, \quad v$. parahaemolyticus strain 93 genomic DNA digested with HindIII; 3, genomic DNA of $E$. coli strain XL1-Blue digested with HindIII; 4, HindIII-digested pVH21 DNA; 5, HindIII insert fragment of plasmid pVH21.

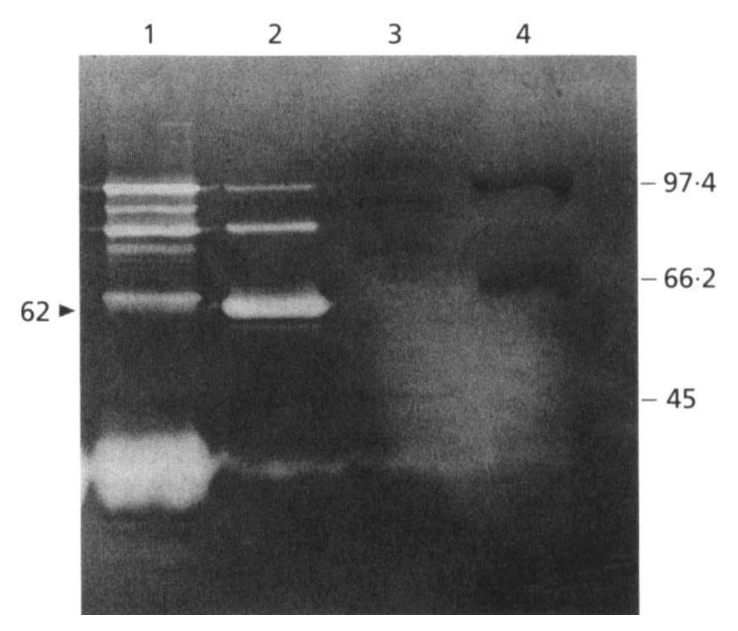

Fig. 2. Detection of protease activities in culture supernatant fraction concentrates by gelatin-SDS-PAGE. Crude protease preparations from the culture supernatant fraction of $V$. parahaemolyticus strain 93 (lane 1), E. coli(pLS101) (lane 2) and E. coli(puC119) (lane 3) are shown. Lane 4, protein molecular mass (kDa) markers.

activity by gelatin-SDS-PAGE. A predominant protease band $(62 \mathrm{kDa})$ and two relatively weak protease bands $(97 \mathrm{kDa}, 86 \mathrm{kDa})$ from extracts of $E$. coli(pLS101) and $V$. parabaemolyticus strain 93 were visible (Fig. 2). Bands with proteolytic activity were not present in concentrates from E. coli(pUC119). Fig. 2 shows that 92,79 and $42 \mathrm{kDa}$ 


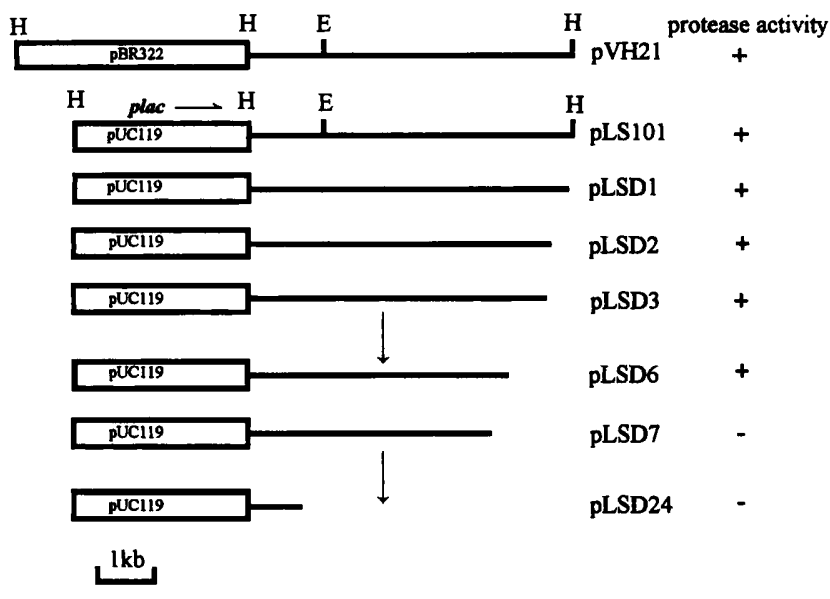

Fig. 3. Construction of a series of deletion derivatives of plasmid pVH21 using exonuclease and the protease activities of transformants bearing these derivatives. pVH21 contains the protease gene prtVp. The plac arrow indicates the direction of transcription of prtVp. Plasmid pLS101 contains prtVp under lac promoter control. Plasmids pLSD1-pLSD24 were created by unidirectional deletion and subcloning. The proteolytic phenotype of the $E$. coli strain XL1-Blue carrying the different plasmids is indicated and was monitored by the presence of a halo in the gelatin agar plates. Vertical arrows indicate deletion derivatives pLSD4 and pLSD5 and pLSD8-pLSD23, respectively. $\mathrm{H}$ and $E$ indicate restriction sites of HindIII and EcoRI, respectively.

protease bands that are present in the extract of $V$. parabaemolyticus strain 93 are absent in the recombinant $E$. coli(pLS101). Three bands $(62,86$ and $97 \mathrm{kDa})$ of protease activity were observed for E. coli(pLSD6), giving an identical result to that for $E$. coli(pLS101) (data not shown).

\section{Expression of protease in E. coli}

Protease activity of the recombinant E. coli(pLS101) increased when it was grown on gelatin-LB agar containing $0.016 \%$ IPTG (data not shown). This result suggests that the inserted $5.8 \mathrm{kbp}$ DNA fragment in pLS101 is oriented in the same direction with respect to the lac promoter for expression of protease activity in $E$. coli. The plasmid pLS101 was subjected to unidirectional deletions as described in Methods. A series of deletion fragments was subcloned in pUC119 and the E. coli transformants were tested for protease activity on gelatinLB agar. The results are shown in Fig. 3.

\section{Nucleotide sequence of prtVp}

The DNA sequence was determined for the smallest DNA fragment which still encoded protease activity. This DNA fragment was present in plasmid pLSD6. The nucleotide sequence of $p r t V p$ and its flanking regions is shown in Fig. 4. Analysis of the nucleotide sequence revealed the presence of one ORF, starting with ATG at nucleotide position 272 and terminating with TGA at position 2033. A putative Shine-Dalgarno sequence (262-264) was found $10 \mathrm{bp}$ upstream from the ATG start codon. The predicted -10 and -35 regions of the promoter sequence are at positions 226 through 231 and 207 through 212, respectively. The ORF encodes a 587 amino acid protein. A putative signal peptide of 25 amino acids was found, which resembled a typical signal peptide sequence for secreted proteins of prokaryotic origin. A potential signal peptidase cleavage site (Ser-25-Phe-26) conforms to the $-3,-1$ rule (von Heijne, 1986). The mature protein has a predicted molecular mass of 63156 $\mathrm{Da}$ and a predicted isoelectric point of 4.53 . The GC content of $48.87 \%$ is in agreement with that of $V$. parabaemolyticus, which is 38-63\% (Baumann \& Schubert, 1984). Hydrophobic amino acids were observed in the initial amino acid sequence in the hydropathy profile. The mean hydrophobicity of the mature protein is $-4 \cdot 1$, suggesting that the protein is hydrophilic in nature.

\section{Comparison of PrtVp with other proteases}

The deduced amino acid sequence of the protease $\mathrm{PrtVp}$ was compared with sequences in the IG-Suite EMBL/ GenBank/DDBJ databases. Similarity comparisons showed that the amino acid sequence of the mature protease has $32 \%$ identity with the sequence of collagenase from $V$. alginolyticus (Takeuchi et al., 1992). A central region of the deduced collagenase amino acid sequence (167 amino acids) from $V$. alginolyticus showed $44 \%$ identity. The alignment of these sequences is shown in Fig. 5. The conserved domain of zinc-metalloproteases, HEXXH (Häse \& Finkelstein, 1993), is also observed in the amino acid sequence of this PrtVp protease. The amino acids in the active site and the zinc-binding site are all conserved at position His-435-His-439. The comparison of the amino acid sequences of the conserved domain between the $V$. parahaemolyticus strain 93 prt gene product and other metalloproteases is shown in Table 2.

\section{Effect of protease inhibitors on enzyme activity}

Crude protease from the culture supernatant fraction of transformant $E$. coli(pLS101) was prepared. The protease activity could be inhibited by the metal chelator EDTA $(10 \mathrm{mM})$ and the zinc-specific chelator 1,10-phenanthroline $(10 \mathrm{mM})$. The enzyme was resistant to inhibitors of serine and cysteine proteases, such as PMSF $(10 \mathrm{mM})$ and aprotinin $\left(30 \mu \mathrm{g} \mathrm{ml}^{-1}\right)$. It was also resistant to pepstatin $A(10 \mathrm{mM})$, an inhibitor of aspartate proteases. The sensitivity of the protease to metal chelators indicates that this PrtVp is a metalloprotease.

\section{Haemolytic assay of the crude extracellular protease}

The haemolytic activities of $E$. coli(pLS101), E. coli(pUC119) and $V$. parabaemolyticus strain 93 extracellular protease were examined in the absence or presence of EDTA. The crude extracellular protease of wild-type strain $V$. parabaemolyticus 93 showed clear haemolytic activity on blood agar in either the presence or absence of $10 \mathrm{mM}$ EDTA, whereas that of transformant $E$. coli(pLS101) was relatively weak on blood agar only in the absence of EDTA. The transformant E. coli(pUC119) had no detectable haemolytic activity on blood agar. These 
1 AGTTGAGCTAATAACTAACTTTTTGGTCTGGTGCGATAAATTTCATTTTTTGAGTCACTTTTGACTCATATTGAC

76 TTATTTAGAAAAAGGTAAATTAATGTTTTTATTAATAATTATTGAATCTTCCTGTGTGGGATTGGTCCCATTAAA $-35$

151 TTAGAGTAATAATTCTATTTTTGGGATCGGTTTCATAAATTTTATGATACTGATTTCACTGTTTGAGCTGTAAGG $-10$ SD

226 AATATAAACCCCACTCAATTTATTTTTATAATCAATGAGTGTTGTTATGTCTCATATCCGTTTTTTCCCGCGTCA

301 TCGTTTGGCGCTTGCTTGCATGCTAGCGAGTGTTTCTAGCTTCTCTTTTGCCCAAAATCAGTGTGCTGTTGCTGA $\begin{array}{llllllllllllllllllllllllll}R & L & A & L & A & C & M & L & A & S & V & S & S & F & S & \downarrow & F & A & Q & N & Q & C & A & V & A & D\end{array}$ 376 TTTACAACAATCGCGTGATTTGGCCGCTGCCGTTTCTGGCGCTGAATATGATTGCTACCACGCTTGGTTCTCTGC $\begin{array}{lllllllllllllllllllllllll}L & Q & Q & S & R & D & L & A & A & A & V & S & G & A & E & Y & D & C & Y & H & A & W & F & S & A\end{array}$ 451 GCCTTCAGCAACGCTGAATGATATTTATAGCGAAGCAAGTTTAAGCCGCATTCAAGTCGCGTTGGATCAAGAAAT $\begin{array}{lllllllllllllllllllllllll}P & S & A & T & L & N & D & I & Y & S & E & A & S & L & S & R & I & Q & V & A & L & D & Q & E & I\end{array}$ 526 TGCACGCTATCGTGGTGAAGCAGAACAAGCTCGCGTTCTAGAAAATCTAGGCGAATTTGTTCGTGCGGCGTATTA $\begin{array}{llllllllllllllllllllllllll}A & R & Y & R & G & E & A & E & Q & A & R & V & L & E & N & L & G & E & F & V & R & A & A & Y & Y\end{array}$ 601 CGTTCGTTACAACGCTGGCACTGGCACACCTGAGTTTTCAGAAGCATTGAGTCAGCGTTTTGCTCAGTCAACGAA $\begin{array}{lllllllllllllllllllllllll}V & R & Y & N & A & G & T & G & T & P & E & F & S & E & A & L & S & Q & R & F & A & Q & S & T & N\end{array}$ 676 CCTGTTCCTCAACAACCCTCATGCTTTGGATCAAGGCCGTGAGCAAGTTGGCGCAATGAAGAGCCTGACTTTGAT $\begin{array}{lllllllllllllllllllllllll}L & F & L & N & N & P & H & A & L & D & Q & G & R & E & Q & V & G & A & M & K & S & L & T & I & M\end{array}$ 751 GGTTGATAACGTGAAGCAGTTGCCGCTGACCATGGATAGCATGATAGCCGCGTTGATGCACTTTAACCGTGACAC $\begin{array}{lllllllllllllllllllllllll}V & D & N & V & K & Q & L & P & L & T & M & D & S & M & I & A & A & L & M & H & F & N & R & D & T\end{array}$ 826 CGCGAAAGACACCCAATGGGTTGATGGCCTGAACAACTTGTTTCGCTCTATGGCAGGTCACGCGGCGAACGATGC $\begin{array}{llllllllllllllllllllllllll}A & K & D & T & Q & W & V & D & G & L & N & N & L & F & R & S & M & A & G & H & A & A & N & D & A\end{array}$ 901 GTTCTACCGCTACATGGCAAACAACACTCACCATATTGATACGTTAGCGCGATTCGCTTCAGACAATGCATGGGC $\begin{array}{lllllllllllllllllllllllll}F & Y & R & Y & M & A & N & N & T & H & H & I & D & T & \text { L } & A & R & F & A & S & D & N & A & W & A\end{array}$ 976 GTTAGATACAGATGCAAACTTTATCGTTTTCAATGCATTACGTGAAACTGGCCGCTTACTTGCGAGCCCAGATCA $\begin{array}{lllllllllllllllllllllllll}L & D & T & D & A & N & F & I & V & F & N & A & L & R & E & T & G & R & L & L & A & S & P & D & Q\end{array}$ 1051 AGAAACCAAACGTAAAGCATTGGCTGTTATGCAGCAAGTGATGCAGCGTTATCCATTGGGCAGTGAGCACGACAA $\begin{array}{llllllllllllllllllllllllllll} & E & T & K & R & K & A & L & A & V & M & Q & Q & V & M & Q & R & Y & P & L & G & S & E & H & D & K\end{array}$

1126 ACTGTGGCTTGCCGCCGTTGAGATGATGAGTTACTACGCGCCTGAGGGTTTGAATGGTCTAAACCTAGAGCAAGC $\begin{array}{llllllllllllllllllllllllll} & \text { L } & \text { W } & L & \text { A } & A & V & E & M & M & S & Y & Y & A & P & E & G & L & N & G & L & N & L & E & Q & A\end{array}$

1201 GAACGAAGATCTAGCAGCACGCGTGATGCCAAATCGTTTTGAATGTCAGGGACCTGCCATCATTCGCTCTGAAGA $\begin{array}{lllllllllllllllllllllllllll}N & E & D & L & A & A & R & V & M & P & N & R & F & E & C & Q & G & P & A & I & I & R & S & E & D\end{array}$ 1276 TCTCTCCGATGCTCAAGCTGCGAAAGCGTGTGAAGTGCTTGCTGCGAAAGAAGCAGACTTCCATCAAGTTGCGAA $\begin{array}{llllllllllllllllllllllllll}L & S & D & A & Q & A & A & K & A & C & E & V & L & A & A & K & E & A & D & F & H & Q & V & A & N\end{array}$

1351 TACTGGTAATCAACCAGTGGCGGATGACTTGAACGATCGTGTTGAAGTCGCGGTGTTTGCAAGCAACGACAGTTA $\begin{array}{lllllllllllllllllllllllll}T & G & N & Q & P & V & A & D & D & L & N & D & R & V & E & V & A & V & F & A & S & N & D & S & Y\end{array}$ 1426 CGTTGATTACTCTTCATTCCTGTTTGGCAATACAACGGATAACGGTGGTCAGTACTTAGAGGGGACTCCGTCAAG $\begin{array}{lllllllllllllllllllllllllll}V & D & Y & S & S & F & L & F & G & N & T & T & D & N & G & G & Q & Y & L & E & G & T & P & S & R\end{array}$ 1501 AGCCGATAATACGGCGCGTTTTGTGGCTTATCGCTACGCGAATGGCGAAGATCTATCTATTTTGAACCTTGAGCA $\begin{array}{lllllllllllllllllllllllllll}A & D & N & T & A & R & F & V & A & Y & R & Y & A & N & G & E & D & L & S & I & L & N & L & E & H\end{array}$ 1576 CGAGTACACTCACTACTTGGATGCACGTTTCAACCAATACGGTTCATTCAGCGACAACTTAGCTCATGGTCATAT $\begin{array}{lllllllllllllllllllllllllll}E & Y & T & H & Y & L & D & A & R & F & N & Q & Y & G & S & F & S & D & N & \text { L } & A & H & G & H & I\end{array}$

1651 CGTTTGGTGGCTGGAAGGCTTTGCGGAATACATGCATTACAAACAAGGTTACAAGGCCGCGATCGATCTGATCCC $\begin{array}{lllllllllllllllllllllllllll}V & W & W & L & E & G & F & A & E & Y & M & H & Y & K & Q & G & Y & K & A & A & I & D & L & I & P\end{array}$

1726 AAGTGGTAAACTGAGCCTGTCAACCGTGTTTGACACCACATACTCGCACGATAGCAACCGCATTTACCGTTGGGG $\begin{array}{llllllllllllllllllllllllllll}S & G & K & L & S & L & S & T & V & F & D & T & T & Y & S & H & D & S & N & R & I & Y & R & W & G\end{array}$

1801 CTACTTGGCGGTTCGCTTCATGCTAGAAAACCACCCTCAAGATGTAGAGAGCTTGTTGGCGTTGTCTCGTTCAGG $\begin{array}{llllllllllllllllllllllllll}Y & L & A & V & R & F & M & L & E & \text { N } & H & P & Q & D & \text { V } & \text { E } & \text { S } & \text { L } & \text { L } & A & \text { L } & S & R & S & G\end{array}$ 1876 TCAGTTTGCACAATGGGCGCACGAGGTTACTGTGCTTGGTCAACAATACGATGCGGAATTTGAGCGTTGGTTGGA $\begin{array}{llllllllllllllllllllllllll}Q & F & A & Q & \text { W } & A & H & E & V & T & V & \text { L } & G & Q & Q & \text { Y } & D & A & E & F & E & R & W & L & D\end{array}$ 1951 TACGTTAGAAGTGGTAGTTGAACCGGAGCAACCAGGAACGGACCCAGAAGAGCCAAGCAGACCACCGATCCTGAA $\begin{array}{lllllllllllllllllllllllll}T & L & E & V & V & V & E & P & E & Q & P & G & T & D & P & E & E & P & S & R & P & P & I & L & K\end{array}$

2026 GTGCAAGTGACGGAGCTGGCGGCGAACCAAAGCCTTCAACTGAGTGGCG C $\mathrm{K}$ -

Fig. 4. Nucleotide sequence of the $V$. parahaemolyticus protease gene and its deduced amino acid sequence. The putative Shine-Dalgarno (SD) sequence and the -10 and the -35 regions of the promoter are indicated. The arrow pointing downwards indicates a possible signal peptide cleavage site. The stop codon is indicated by a horizontal bar. 


\begin{tabular}{|c|c|}
\hline \multirow{2}{*}{ VPPRT } & 321 \\
\hline & NRFECQGPAI I RSEDLSDAQAAKACEVLAAKEADFHQV \\
\hline VACOLL & $\begin{array}{l}1 \\
\text { QTYTCSPTIRILSQNMTQEQHAAACSKMGYEEGYFHQS } \\
362\end{array}$ \\
\hline VPPRT & ANTGNQPVADDLNDRVEVAVFASNDSYVDYSS FLFGNT \\
\hline VACOLL & 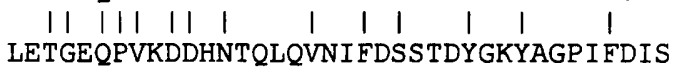 \\
\hline VPPRT & TDNGGQYLEGTPSRADNTARFVAY--RYANGEDLS ILN \\
\hline & $11111111111 \quad 1 \quad 111$ |11 | \\
\hline VACOLL & $\begin{array}{l}\text { TDNGGMYLEGDPSOPGNI PNFIAYEASYAN-ADHFVWN } \\
\quad * \quad *\end{array}$ \\
\hline VPPRT & LEHEYTHYLDAR FNQYGS FSDNLAHGHIVWWLEGFAEY \\
\hline & 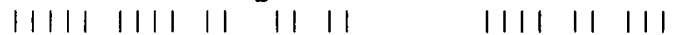 \\
\hline VACOLL & $\begin{array}{l}\text { LEHEYVHYLDGRFDLYGGFS--HPTEKIVWWSEGIAEY } \\
487\end{array}$ \\
\hline VPPRT & MHYKQGYKAAIDLIPSG \\
\hline & $\begin{array}{lll}11 & 1 & 1\end{array}$ \\
\hline VACOLL & $\begin{array}{l}\text { VAQENDNQAALET ILDG } \\
527\end{array}$ \\
\hline
\end{tabular}

Fig. 5. Alignment of the deduced amino acid sequences from $V$. parahaemolyticus strain 93 PrtVp protease (VPPRT) and that of the central portion of $V$. alginolyticus collagenase (VACOLL) (Takeuchi et al., 1992). The conserved domain of zincmetalloprotease is indicated by the asterisks (zinc-binding sites) and circle (active site).

results indicate that $\operatorname{PrtVp}$ is able to cause haemolysis but is not the major haemolytic factor of $V$. parabaemolyticus strain 93 .

\section{DISCUSSION}

Cloning in $E$. coli of a protease gene from $V$. parabaemolyticus has not been reported so far. In this study, the gene encoding an extracellular protease of $V$. parabaemolyticus strain 93 was successfully cloned and sequenced. A single ORF of 1761 nucleotides encodes a large polypeptide (587 amino acids) with a signal sequence of 25 amino acids. The deduced molecular mass of the mature polypeptide, $63 \mathrm{kDa}$, correlates well with the value determined by SDS-PAGE for the protease from $V$. parabaemolyticus. Gelatin-SDS-PAGE analysis revealed the presence of multiple proteases of different sizes in the ammonium sulphate precipitate of the culture supernatant fraction of $E$. coli(pLS101) or E. coli(pLSD6). Protease activity was detected as one major band corresponding to a molecular mass of $62 \mathrm{kDa}$, with two weaker bands at 97 and $86 \mathrm{kDa}$. It is not likely that pLSD6 contains two or three distinct protease genes since the length of the nucleotide sequence of the flanking region of $p r t V p$ is too small to code for the $97 \mathrm{kDa}$ and $86 \mathrm{kDa}$ proteins. The relationship between these weaker bands and the major $62 \mathrm{kDa}$ protease is still unclear and remains to be resolved.

We found no amino acid sequence similarity of the $p r t V p$ gene product with those of any of the published Vibrio proteases and other proteases such as Bacillus thermolysin (Titani et al., 1972), Pseudomonas elastase (Fukushima et al., 1989), Pseudomonas alkaline proteinase (Okuda et al., 1990) and Serratia proteinase (Nakahama et al., 1986). However, the deduced amino acid sequence shared $32 \%$ identity with that of the $V$. alginolyticus collagenase (Fig. 5). This result suggests that these Vibrio proteases may belong to a new family of proteases, but further work is necessary to prove this hypothesis.

PrtVp may be regarded as a zinc-metalloprotease because the primary sequence motif $\mathrm{HEXXH}$ was found in $\mathrm{PrtVp}$ (His-435, His-439 and Glu-436). In the process of catalysis, the importance of the amino acid structure of His-Glu-Xaa-Xaa-His in facilitating electron transfer with zinc was reported previously by Häse \& Finkelstein (1993). The catalytic site as well as the zinc-binding site of the Bacillus thermoproteolyticus protease and those of other metalloproteases of the Vibrio species and the predicted sites of the $V$. parabaemolyticus metalloprotease are conserved. In addition, the inhibition by zinc- and metalspecific inhibitors indicates that $\mathrm{PrtVp}$ binds a zinc ion at this conserved zinc-binding site. Several other bacterial zinc-metalloproteases have been shown to be extracellular proteins which need a signal sequence to aid transport across the bacterial cell membranes (David et al., 1992; Milton et al., 1992; Nishina et al., 1992; Booth et al., 1983). Our protease has also been found to have a typical signal peptide.

Table 2. Comparison of zinc-metalloprotease motifs between the PrtVp conserved domain and conserved domains from other zinc-metalloproteases

\begin{tabular}{|llll|}
\hline Bacterial sp. & $\begin{array}{c}\text { Amino acids of } \\
\text { conserved } \\
\text { domains* }\end{array}$ & $\begin{array}{c}\text { Amino acid } \\
\text { residues in } \\
\text { appropriate } \\
\text { sequence }\end{array}$ & \multicolumn{1}{c|}{ Reference } \\
\hline Bacillus thermoproteolyticus & HELTH & $142-146$ & Titani et al. $(1972)$ \\
Vibrio proteolyticus & HEVSH & $343-347$ & David et al. $(1992)$ \\
Vibrio anguillarum & HEVSH & $346-350$ & Milton et al. $(1992)$ \\
Vibrio cholerae & HEVSH & $343-347$ & Häse \& Finkelstein (1991) \\
Vibrio alginolyticus & HEYVH & $477-481$ & Takeuchi et al. $(1992)$ \\
V'ibrio parabaemolyticus 93 & HEYTH & $435-439$ & This study \\
\hline
\end{tabular}

* $\mathrm{H}$, Zinc-binding sites; $\mathrm{E}$, active site. 
There has been limited study of the proteases of $V$. parahaemolyticus. Previously, Iuchi \& Tanaka (1982) separated and characterized four extracellular proteases of $V$. parabaemolyticus by polyacrylamide slab gel electrophoresis. These proteases comprised two serine proteases and two metalloproteases as characterized by enzyme inhibitor studies. However, the authors did not determine the molecular mass of the proteases they identified. Sarkar et al. (1987b) reported that a $65 \mathrm{kD}$ a protein isolated from Kanagawa-positive strains of $V$. parabaemolyticus was observed in SDS-PAGE. The authors also concluded that this $65 \mathrm{kDa}$ protein may play a vital role in the pathogenesis of the disease caused by $V$. parahaemolyticus based on the mouse lethality test (Sarkar et al., 1987b). In their study, about $26 \%$ of the Kanagawa-phenomenon-positive strains isolated from clinical sources demonstrated the presence of this $65 \mathrm{kDa}$ protein along with the $21 \mathrm{kDa}$ TDH in SDS-PAGE, but whether this $65 \mathrm{kDa}$ protein has protease activity is unknown (Sarkar et al., 1987b). Whether this $65 \mathrm{kDa}$ protein is related to that characterized herein also remains to be clarified. The isolation and purification of the $p r t V p$-encoded $62 \mathrm{kDa}$ protein for testing of animal lethal activity is required.

Many extracellular bacterial proteases have been suggested to play important roles in virulence. The extracellular protease of Vibrio vulnificus digested all haem proteins tested and elicited haem liberation from the proteins (Nishina et al., 1992). The authors suggest that the protease contributes to the efficient utilization of haem by $V$. vulnificus. Recently, Finkelstein et al. (1992) proposed that haemagglutinin/protease of $V$. cholerae may act as a detachase which allows the bacterium to detach from host cell membranes and then to disseminate to other hosts. The alkaline protease of Pseudomonas aeruginosa is required for the tissue destruction observed in corneal infections by this species (Howe \& Iglewski, 1984). A metalloprotease of Aeromonas salmonicida has been shown to produce lesions upon injection into trout and has been suggested as a virulence factor (Ellis, 1991). Vibrio anguillarum metalloprotease $(36 \mathrm{kDa})$ and a $75 \mathrm{kDa}$ protease or $30 \mathrm{kDa}$ protease may also work together to enhance the pathogenicity of $V$. anguillarum (Milton $e t$ al., 1992).

Our future investigations will concern mutagenesis of the protease gene of $V$. parabaemolyticus strain 93 and animal infection studies to assess the role of the metalloprotease in the virulence of $V$. parabaemolyticus.

\section{ACKNOWLEDGEMENTS}

This work was supported by grant NSC 84-2321-B-002-077 from the National Science Council, Taipei, Taiwan, Republic of China.

\section{REFERENCES}

Ausubel, F. M., Brent, R., Kingston, R. E., Moore, D. D., Seidman, J. G., Smith, J. A. \& Struhl, K. (1987). Current Protocols in Molecular Biology. New York: John Wiley.

Baumann, P. \& Schubert, R. H. W. (1984). Vibrionaceae. Section 5.
In Bergey's Manual of Systematic Bacteriology, vol. 1, pp. 518-538. Edited by N. R. Krieg \& J. G. Holt. London: Williams \& Wilkins.

Bolivar, F., Rodriguez, R. L., Greene, P. J., Betlach, M. C., Heynecker, H. L., Boyer, H. W., Crosa, J. H. \& Falkow, S. (1977). Construction and characterization of new cloning vehicles. II. A multipurpose cloning system. Gene 2, 95-113.

Booth, B. A., Boesman-Finkelstein, M. \& Finkelstein, R. A. (1983). Vibrio cholerae soluble hemagglutinin/protease is a metalloenzyme. Infect Immun 42, 639-644.

Booth, B. A., Boesman-Finkelstein, M. \& Finkelstein, R. A. (1984). Vibrio cholerae hemagglutinin/protease nicks cholera enterotoxin. Infect Immun 45, 558-560.

Bullock, W. O., Fernandez, J. M. \& Short, J. M. (1987). XL1-Blue: a high efficiency plasmid transforming recA Escherichia coli strain with $\beta$-galactosidase selection. BioTechniques 5, 376-378.

Chang, Y. C. \& Wu, G. E. (1992). A simple and rapid procedure for pouring sequencing gels. BioTechniques 12, 78.

Chowdhury, M. A. R., Miyoshi, S. I. \& Shinoda, S. (1991a). Vascular permeability enhancement by $V$ ibrio mimicus protease and the mechanisms of action. Microbiol Immunol 35, 1049-1058.

Chowdhury, M. A. R., Miyoshi, S. I. \& Shinoda, S. (1991b). Role of Vibrio mimicus protease in enterotoxigenicity. J Diarrboeal Dis Res 9 , 332-334.

Dai, J. H., Lee, Y. S. \& Wong, H. C. (1992). Effects of iron limitation on production of a siderophore, outer membrane proteins, and hemolysin and on hydrophobicity, cell adherence, and lethality for mice of Vibrio parabaemolyticus. Infect Immun 60, 2952-2956.

David, V. A., Deutch, A. H., Sloms, A., Pswbk, D., Ally, A. \& Durham, D. R. (1992). Cloning, sequencing and expression of the gene encoding the extracellular neutral protease, vibriolysin, of Vibrio proteolyticus. Gene 112, 107-112.

Deane, S. M., Robb, F. T. \& Woods, D. R. (1986). Isolation and characterization of a Vibrio alginolyticus mutant that overproduces extracellular proteases. J Gen Microbiol 132, 893-898.

Deane, S. M., Robb, F. T., Robb, S. M. \& Woods, D. R. (1989). Nucleotide sequence of the Vibrio alginolyticus calcium dependent, detergent-resistant alkaline serine exoprotease A. Gene 76, 281-288.

Dowling, J. N., Saha, A. K. \& Glew, R. H. (1992). Virulence factors of the family Legionellaceae. Microbiol Rev 56, 32-60.

Ellis, A. E. (1991). An appraisal of the extracellular toxins of Aeromonas salmonicida ssp. salmonicida. J Fish Dis 14, 265-277.

Finkelstein, R. A., Boesman-Finkelstein, M., Chang, Y. \& Häse, C. C. (1992). Vibrio cholerae hemagglutinin/protease, colonial variation, virulence, and detachment. Infect Immun 60, 472-478.

Fukushima, J., Yamamoto, S., Morihara, K., Atsumi, Y., Takeuchi, H., Kawamoto, S. \& Okuda, K. (1989). Structural gene and complete amino acid sequence of Pseudomonas aeruginosa IFO 3455 elastase. $J$ Bacteriol 171, 1698-1704.

Häse, C. C. \& Finkelstein, R. A. (1991). Cloning and nucleotide sequence of the Vibrio cholerae hemagglutinin/protease (HA/ protease) gene and construction of an $\mathrm{HA} /$ protease-negative strain. J Bacteriol 173, 3311-3317.

Häse, C. C. \& Finkelstein, R. A. (1993). Bacterial extracellular zinccontaining metalloproteases. Microbiol Rev 57, 823-837.

von Heijne, G. (1986). A new method for predicting signal sequence cleavage sites. Nucleic Acids Res 14, 4683-4690.

Henikoff, S. (1984). Unidirectional digestion with exonuclease III creates targeted breakpoints for DNA sequencing. Gene 28, 351-359.

Heussen, C. \& Dowdle, E. B. (1980). Electrophoretic analysis of plasminogen activators in polyacrylamide gels containing sodium 
dodecyl sulphate and copolymerized substrates. Anal Biochem 102, 196-202.

Honda, T., Shimizu, M., Takeda, Y. \& Miwatani, T. (1976). Isolation of a factor causing morphological changes of Chinese hamster ovary cells from the culture filtrate of Vibrio parabaemolyticus. Infect Immun 14, 1028-1033.

Howe, T. R. \& Iglewski, B. H. (1984). Isolation and characterization of alkaline protease-deficient mutants of Pseudomonas aeruginosa in vitro and in a mouse eye model. Infect Immun 43, 1058-1063.

luchi, S. \& Tanaka, S. (1982). Separation of four extracellular proteases of Vibrio parabaemolyticus by polyacrylamide gel electrophoresis. FEMS Microbiol Lett 15, 129-132.

Janda, J. M., Powers, C., Bryant, R. G. \& Abbott, S. I. (1988). Current perspectives on the epidemiology and pathogenesis of clinically significant Vibrio spp. Clin Microbiol Rev 1, 245-267.

Kho, C. J. \& Zarbl, H. (1992). A rapid and efficient protocol for sequencing plasmid DNA. BioTechniques 12, 228-230.

Lee, C.-Y. \& Pan, S. F. (1993). Rapid and specific detection of the thermostable direct haemolysin gene in Vibrio parabaemolyticus by the polymerase chain reaction. J Gen Microbiol 139, 3225-3231.

Miller, J. H. (1972). Experiments in Molecular Genetics. Cold Spring Harbor, NY: Cold Spring Harbor Laboratory.

Milton, D. L., Norqvist, A. \& Wolf-Watz, H. (1992). Cloning of a metalloprotease gene involved in the virulence mechanism of Vibrio anguillarum. J Bacteriol 174, 7235-7244.

Nakahama, K., Yoshimura, K., Marumoto, R., Kikuchi, M., Lee, I. S., Hase, T. \& Matsubara, H. (1986). Cloning and sequencing of Serratia protease gene. Nucleic Acids Res 14, 5843-5855.

Nishibuchi, M., Fasano, A., Russell, R. G. \& Kaper, J. B. (1992). Enterotoxigenicity of Vibrio parabaemolyticus with and without genes encoding thermostable direct hemolysin. Infect Immun 60 , 3539-3545.

Nishina, Y., Miyoshi, S. I., Nagase, A. \& Shinoda, S. (1992). Significant role of an exocellular protease in utilization of heme by Vibrio vulnificus. Infect Immun 60, 2128-2132.

Norqvist, A., Norrman, B. \& Wolf-Watz, H. (1990). Identification and characterization of a zinc metalloprotease associated with invasion by the fish pathogen Vibrio anguillarum. Infect Immun 58, 3731-3736.

Okuda, K., Morihara, K., Atsumi, Y., Takeuchi, H., Kawamoto, S., Kawasaki, H., Suzuki, K. \& Fukushima, J. (1990). Complete nucleotide sequence of the structural gene for alkaline protease from Pseudomonas aeruginosa IFO 3455. Infect Immun 58, 4083-4088.

Sanger, F., Nicklen, S. \& Coulson, A. R. (1977). DNA sequencing with chain-terminating inhibitors. Proc Natl Acad Sci USA 74, 5463-5467.

Sarkar, B. L., Kumar, R., De, S. P. \& Pal, S. C. (1987a). Hemolytic activity of the lethal toxin production by environmental strains of Vibrio parabaemolyticus. Appl Environ Microbiol 53, 2696-2698.

Sarkar, B. L., Kumar, R., De, S. P. \& Pal, S. C. (1987b). Observation on a 65 -kilodalton protein isolated from Kanagawa positive strains of Vibrio parabaemolyticus. Can J Microbiol 33, 1113-1116.

Sutcliffe, J. G. (1979). Complete nucleotide sequence of the Escherichia coli plasmid pBR322. Cold Spring Harbor Symp Quant Biol 43, 77-90.

Takeuchi, H., Shibano, Y., Morihara, K., Fukushima, J., Inami, S., Kell, B., Gilles, A. M., Kawamoto, S. \& Okuda, K. (1992). Structural gene and complete amino acid sequence of Vibrio alginolyticus collagenase. Biochem J 281, 703-708.

Titani, K., Hermodson, M. A., Ericsson, L. H., Walsh, K. A. \& Neurath, H. (1972). Amino-acid sequence of thermolysin. Nat New Biol 238, 35-37.

Vieira, J. \& Messing, J. (1982). The pUC plasmids, an M13mp7derived system for insertion mutagenesis and sequencing with synthetic universal primers. Gene 19, 259-268.

Vieira, J. \& Messing, J. (1987). Production of single-stranded plasmid DNA. Methods Enzymol 153, 3-11.

Wilbur, W. J. \& Lipman, D. J. (1983). Rapid similarity searches of nucleic acid and protein data banks. Proc Natl Acad Sci USA 80, 726-730.

Yoh, M., Miwatani, T. \& Honda, T. (1992). Comparison of Vibrio parabaemolyticus hemolysin (VP-TRH) produced by environmental and clinical isolates. FEMS Microbiol Lett 92, 157-162.

Received 20 March 1995; revised 28 June 1995; accepted 10 July 1995. 